西

DE GRUYter DOI: 10.1515/plass-2016-0003

Ewelina Żmijewska ${ }^{1,2}$, Anna Linkiewicz ${ }^{1,2^{*}}$, Magdalena Żurawska-Zajfert ${ }^{1,2}$, Katarzyna Grelewska-Nowotko ${ }^{1,2}$, Sławomir Sowa ${ }^{1,2}$, Janusz Zimny ${ }^{2}$

GMO Controlling Laboratory, Plant Breeding and Acclimatization Institute- National Research Institute ${ }^{1}$, Plant Biotechnology and Cytogenetics Department, Plant Breeding and Acclimatization Institute- National Research Institute ${ }^{2}$;

*Corresponding author: a.linkiewicz@ihar.edu.pl

\title{
CHARACTERISTICS OF CRY1AB PROTEIN FROM BIOINSECTICIDES AND INSECT RESISTANT GM CROPS
}

\begin{abstract}
Biological insecticides are an effective method used in plant protection. One of the most widely used active substances in biological insecticides is Cryl Ab protein, which is toxic for lepidopteran insects. This protein is produced during bacterial sporulation by Bacillus thuringiensis. Other sources of Cry1 $\mathrm{Ab}$ protein are genetically modified plants (GM) with expression of $c r y l A b$ gene. Cry $1 \mathrm{Ab}$ protein in both bioinsecticides and GM plants is present in the form of protoxin, which requires activation by enzymatic treatment in the gut of susceptible insects. So far, Cry1 Ab mode of action is not fully understood, but there are 3 main concepts describing it. Two of them assume that a toxic protein after binding to receptors in the insect gut penetrates into the cells, causing pore formation in the gut, which leads to the death of the sensitive insect. In the third model Cry1 Ab toxic action is a result of toxin-induced chemical processes initiating a cell death pathway. This work describes the structure and mode of action of Cry1 $\mathrm{Ab}$ protein, present in biological insecticides and genetically modified plants.
\end{abstract}

Key words: biological insecticide; Cry1 Ab protein; Cry protein mode of action; GM plant

\section{INTRODUCTION}

Biological plant protection products are a unique type of pesticides, which are derived from natural materials, such as animals, plants, bacteria or minerals. By April 2016, 299 active ingredients of biological plant protection products were registered and used in 1401 registered pesticides in the United States of

Communicated by Grzegorz Żurek 
America (USA) (US EPA, 2016). Substances containing Bacillus thuringiensis Berliner crystal proteins are the most commonly used biological plant protection products. Insecticidal properties of $\mathrm{Cry} 1 \mathrm{Ab}$ protein produced by $B$. thuringiensis are known since the beginning of the $20^{\text {th }}$ century. Nowadays its insecticidal activity on lepidopteran insects is used to reduce losses caused by pests in vegetable crops, orchards and forests. Although biopesticides are not currently used in the European Union (EU) for maize protection their potential in reduction of chemical insecticide usage against maize pests is large (Meissle et al., 2010). The application of bacterial endospores can also help to reduce the accumulation of Fusarium verticillioides mycotoxins in this crop. Insecticides based on B. thuringiensis endospores are used for control of the European corn borer (ECB) (Ostrinia nubilalis Hbn., Crambidae) in other countries, e.g. the USA. Along with the increase in maize acreage and observed climate changes, the distribution area of this insect has moved to the northern regions of Europe. In Europe, the ECB larvae damage can be found in 20\% (Hungary) or even up to $60 \%$ (Spain) of maize acreage, with estimated yield losses range from 5 to $30 \%$. Economic yield losses are often recorded in Hungary, Italy, Spain, France, Germany and Poland (Meissle et al., 2010). In southern Poland, where maize is intensively grown $O$. nubilalis caterpillars damage $50-80 \%$, and locally even up to $100 \%$ of plants, causing up to $20-30 \%$ and sometimes up to $40 \%$ of direct loss in grain yield (Lisowicz and Tekiela, 2004). Yield losses are not only directly connected to insects foraging but also indirectly by increased susceptibility of damaged plants to pathogen infections, especially Fusarium fungi, which produce dangerous mycotoxins (Saladini et al., 2008). The ECB is relatively difficult to control due to the larvae foraging inside the plant. Protection treatment is cumbersome, expensive and inefficient, and thus systemic insecticides are commonly recommended (Mrówczyński et al. 2005).

$\mathrm{Cry} 1 \mathrm{Ab}$ protein has been used to protect genetically modified (GM) maize varieties, which in many countries have become an alternative to the use of chemical insecticides. The use of genetic modification allows to limit the damage caused by the ECB by up to $97-100 \%$ (Bereś and Gabarkiewicz, 2008). The cultivation of GM crops on a large scale began in 1996 when the global planting area was equal to 1.7 million hectares. In 20 years period the area of GM crops cultivation increased more than 100-fold and reached 179.7 million hectares. In 2015, GM maize was grown on 56.6 million hectares, representing $29 \%$ of the world's total GM crops (James, 2016). In Europe, the only GM maize which has been authorized for cultivation is MON810 line with crylAb gene expression. Two additional GM events of maize (DAS 1507 and Bt11) are in the process of authorization. 


\section{CHARACTERISTICS OF CRY PROTEINS}

B. thuringiensis was isolated for the first time by Ishiwatari in 1901 from death silkworm larvae (Bombyx mori L.). The microorganism has been recognized as its pathogen and named Bacillus sotto. In 1911 Berliner isolated another strain from flour moth larvae (Anagasta kuehniella Zeller) in Germany, hence comes the current name - Bacillus thuringiensis Berliner (Bt) (Milner, 1994). The bacterium B. thuringiensis is a gram-positive bacterium that is commonly found in the dirt and dust of grain elevators and in the soil. Strains of this bacteria are widely distributed in the soil throughout the world but with varying intensity. Martin and Travers (1989) reported that B. thuringiensis in the soil occurs commonly, as it was found in 785 of 1115 analyzed soil samples (70\%). In contrast, DeLucca et al., (1981) analyzing 46373 soil bacterial isolates from 115 fields, found only 250 samples containing $B$. thuringiensis isolates $(0.5 \%)$ from which 94 was B. thuringiensis var. kurstaki. During sporulation of B. thuringiensis Insecticidal Crystal Proteins (ICP) known as Cry proteins or deltaendotoxin are produced. These proteins are toxic to various insect groups and are encoded by cry gene family (Whiteley and Schnepf, 1986). According to Bravo et al. (2011) Cry proteins belong to the class of pore-forming toxins (PFT).

Cry proteins classification is based on their primary amino acid sequence. By 2010, more than 500 different cry genes have been identified and classified into 67 groups (cryl-cry67) (Crickmore, 2010). The nomenclature of these proteins is based solely on amino acid sequence, which is not necessarily associated with similar biological activity. The full protein name contains the word Cry (crystal), followed by Arabic number (primary rank), then the uppercase (secondary rank) and lowercase character (tertiary rank). In the name of the Cry protein the Arabic number may reoccur which means that the protein sequences are identical but independently isolated (quaternary rank). Cry proteins with the same first number, uppercase and lowercase letter, for example Cry1Ab1 and Cry1 Ab2 have 95\% amino acid sequence similarity, while the Cry protein with the same first number and uppercase, for example Cry1 Aa and Cry1 Ab have at least $78 \%$ of common amino acid sequence. Cry proteins which have the same first number, for example Cry1 Ab and Cry1Ba have at least $45 \%$ of the common sequences. The current list of the Cry proteins is available on the University of Sussex website (http://www.lifesci.sussex.ac.uk/home/Neil Crickmore/ Bt/toxins2.html).

The largest group of Cry proteins are tridomain proteins (3D) which includes 53 subgroups (Crickmore et al., 2010). Their structure was first described by Li et al. (1991). It was shown that they are globular molecules, comprising of three different domains linked by individual connectors. 


\section{CRY1AB PROTEIN STRUCTURE AND MODE OF ACTION}

Cry1 Ab protein has 3 domains where domain I consists of $7 \alpha$-helices, with centrally located $\alpha$-helix 5 and six other amphipathic helices surrounding it. Domain II consists of 3 antiparallel $\beta$-sheets "packed" in the form of a $\beta$-barrel ( $\mathrm{Li}$ et al., 1991). Each of the first two $\beta$-sheets consists of four chains with the Greek key motif. The third $\beta$-sheet comprises of three chains arranged in a meander motif and a short $\alpha$-helix domain arranged opposite to domain I with which it interacts (Pigott and Ellar, 2007). The structure of domain II is highly variable, which indicates that this domain is responsible for the Cry proteins specificity. The domain III structure is less variable than the domain II, but more variable than domain I. The domain III is a jelly-roll beta-sandwich consisting of antiparallel $\beta$-sheets. Each of the sheets has 5 chains (Pigott and Ellar, 2007). Two long loops extend from domain III and interact with domain I (Grochulski et al., 1995).

The full length $131 \mathrm{kDa}$ of bacterial protein Cry1 $\mathrm{Ab}$ is named a protoxin and is not toxic in the synthesized form. When this form is dissolved in an alkaline environment ( $\mathrm{pH} 9$ - 10) of insects gastrointestinal tract, it must be activated by proteases present in the gut of susceptible insect. Enzymes hydrolyze the domain I $\alpha 1 \mathrm{~N}$-terminus and catalyze the cleavage of approximately half of the $\mathrm{C}$ terminus sequence, resulting in $60-70 \mathrm{kDa}$ fragments (Gill et al., 1992, Bravo et al., 2002) (Fig.1). Obtained proteins act as an active toxin and are resistant to proteolytic enzymes (Haider and Ellar, 1989; Douville et al., 2001). According to Höfte et al. (1986), the minimum length of Cry1 Ab fragment ensuring insecticidal activity is $564-578$ amino acids which corresponds to a weight of about $60 \mathrm{kDa}$. The site of action of Cry protein is a midgut membrane of the target insect where the $\mathrm{pH}$ is alkaline, between 9 and 11 (Milne and Kaplan, 1993). Cry1A toxins are completely soluble at pH 9.5 (Bietlot et al., 1989).

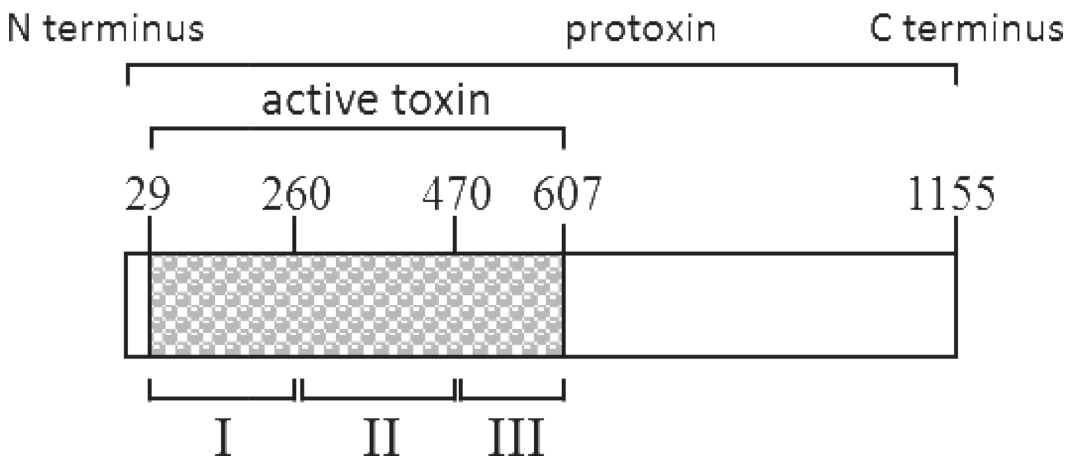

Fig. 1. Graphic representation of bacterial Cry1 Ab protein amino acid sequence. Protoxin 1-1155 aa, active toxin 29-607 aa and three protein domains (I, II, III) (according to Martens et al., 1995)

The domains of the Cry protein are involved in its specific insecticidal activity. Domain II plays a decisive role in the protein action specificity. Domain I is considered to have a main role in oligomerization and pore formation in the cell 
membrane (Li et al., 1991; Grochulski et al., 1995). Hypothesis concerning the role of domain I in pore formation seems to confirm the fact that the helices from $\alpha 3$ to $\alpha 7$ are relatively large (more than $30 \AA$ ) and therefore long enough to "cover" the hydrophobic cell membrane (Pigott and Ellar, 2007). Both the domain II and III determine the protein action specificity to certain insects through the mediation of specific interaction with various proteins in insect gastrointestinal tract (most of the cell membrane receptors binding sites are located in domains II and III). These domains are responsible for binding to the target insect cell membrane, transferring domain I close to the membrane, allowing the formation of pores (Bravo and Soberón, 2007).

Several models of Cry protein action have been described in the literature. In the classical model Cry protein binds to a membrane receptor, then is taken into cells of insect gut to form pores, and thereby destabilizes the function of the cell membrane. By forming of non-selective permeable channels for cations, anions and neutral soluble substances and by water flow cells swell and consequently die. When the process includes many cells, the death of susceptible insect occurs as a result of starvation or infection, only a few days after ingestion of a toxic protein (Knowles, 1994). Besides the classical model, there are other models of Cry protein action: the so called sequential binding model which also implies that the protein toxic action is based on pore formation, and a signal path model, whereby pore formation is insignificant. In 2006 Jurat- Fuentes reported that the toxicity of Cry protein is the result of both osmotic lysis and disturbances in signaling pathway. The common element of all models is solubilisation and activation of the Cry protein in the insect gut in the form of the protoxin by proteases, and specific binding to the gut cell membrane. Such binding of proteins may lead to changes in its conformation, thereby activating its toxicity.

In the model of sequential binding, enzymatically activated monomeric Cry protein form binds to intestinal epithelial cells, resulting in protein conformation changes, necessary for oligomerization and penetration into the membrane to form pores (Soberón et al., 2010). In this model, the first step is the low affinity binding of activated toxin to aminopeptidase N (APN) or alkaline phosphatase (ALP) receptors which are numerously present on the cell membrane surface. By binding Cry protein domain III with ALP and APN, the activated toxin is located within the membrane microvilli, close to cadhedrin receptor (CAD), or cadhedrin-like molecule to which it can bind. The role of ALP and APN after binding is the induction of Cry protein binding to the membrane, leading to pore formation and cell lysis. After binding of CAD with the toxin, $\alpha$-helix removal is induced, resulting in Cry protein oligomers formation. Oligomerization is quicker in alkaline environment, similar to $\mathrm{pH}$ of the lepidopteran midgut (Russel et al., 2004). Binding to CAD is a multiplex reaction when the proteolytic cleavage of the $\mathrm{N}$-terminus containing $\alpha$-helix I of domain I is present, resulting in the exposition of domain I hydrophobic regions. The subsequent 
protein Cry1 Ab oligomer binding to ALP/APN receptors allows pre-pores occurrence that penetrate the membrane and form stable pores. These pores have a high probability of opening, unlike those formed from the action of the protein monomeric form, wherein there is minimal interaction with liposomes, inducing partially closed pores. The binding of Cry oligomers to ALP or APN is reversible, these receptors are not very specific, which may lead to an accumulation of Cry oligomers near the ATP-binding cassette transporters (ABC transporter) a membrane system allowing transfer of small particles through the membrane. Binding with the transport system facilitates oligomers introduction to the inside of the membrane.

Oligomers forming pre-pores can be formed from monomers of the same protein type (homo-oligomers) or from a combination of different types of monomers (hetero-oligomers). One explanation for the synergistic effect of Cry3D protein is that if Cry proteins linked in the oligomer are toxic, the toxicity induced by hetero-oligomer may be greater than the toxicity of each of the homooligomers respectively (Soberón et al, 2000). But there are also studies indicating that the lack of Cry protein mutants toxicity may be a dominant negative (DN) feature. Assuming that DN-mutant forms hetero-oligomers with wild type, they are non-toxic.

An extremely important step in the study of Cry protein action mechanism is the way of penetration to the target insect gut membrane and pore formation. There are two proposed mechanisms of pore formation - umbrella model ( $\mathrm{Li}$ et al., 1991) and penknife model (Hodgmann and Ellar, 1990). Most accepted model of Cry protein binding to the membrane is the model assuming that the hydrophobic structure described as a hairpin consisting of a centrally located $\alpha$ helix 5 and $\alpha$-helix 4 penetrates the membrane phospholipid bilayer, while the rest of the amphipathic domain I helices are distributed on the gut membrane surface in umbrella-like conformation. Formed pores have a size from 1 to 2.6 $\mathrm{nm}$ in diameter and, depending on the $\mathrm{pH}$, may be closed or open. In the penknife model the domain I with central, highly hydrophobic helix $\alpha 5$ and $\alpha 6$ linked by loop "opens" the membrane in a manner similar to a penknife and penetrates inside. The remaining part of Cry protein molecule binds receptors on the membrane surface (Hodgman and Ellar, 1990). In both models, the central position of the domain I ( $\alpha$-helix 5 ) is responsible for the pores formation. In contrast to proposed models some authors claim that the whole protein molecule penetrates the insect gut membrane (Nair and Dean, 2008).

Hypothesis about protein toxicity which would result from leaks caused by the pores in insects gut membrane was questioned by Zhang et al. (2006). In signaling pathway model described by these authors, the protein molecules do not form pores in the gut cell membrane but bind to the membrane receptor, initiating chemical processes leading to cell death. By attaching and integration of Cry protein with cadhedrin, the intracellular signaling pathway is initiated that leads to $\mathrm{G}$ protein activation (signal dependent on the presence of $\mathrm{Mg}^{2+}$ ). 
Activated $G$ protein stimulates a membrane-bound adenylate cyclase (AC) which catalyse cAMP production and activates the kinase A which causes protrutiions in the gut cells, cell swelling, lysis and subsequent death. According to this model, the oligomers are not formed from protein monomeric forms and no pores are formed.

The model described by Jurat-Fuentes (2006) assumes that the cytotoxicity is due to the combined influence of cell osmotic lysis and signaling pathway - elements of both described above models. Firstly activated Cry protein monomer binds to the cadhedrin-like receptor, then activates the signaling pathway regulated by phosphatase. Signaling is directly dependent on Cry proteins interaction with actin (cytoskeletal protein). Upon binding to the cadhedrin-like receptor, Cry monomers are oligomerized and bind to APN receptor. As a result of pore formation, osmotic shock and signal pathway activation occurs, leading to cell death.

Recent studies show that Cry proteins, considered to be specific to only one insects order, may also have activity against other insects groups (Frankenhuyzen, 2013). Author demonstrated the existence of cross-reaction for 27 Cry proteins which are active against more than one insects order. However, the toxic effect is much less pronounced for those insects than for insects with a basic range of specificity for a particular protein. For example Cry1Ba protein manifests main activity against Lepidoptera order but also exhibits toxic effects against beetles (Coleoptera) and flies (Diptera). It was indicated that for Cry protein its specific activity is highly influenced by the pretreatment upon ingestion by an insect, whereby it is dissolved and treated with digestive enzymes (Frankenhuyzen, 2013).

\section{BIOINSECTICIDES WITH B. THURINGENSIS ENDOSPORES}

The first formulation with natural isolate of B. thuringiensis was Sporeineinsecticide registered in France in 1938. In 1961, the bacterial extract of B. thuringiensis var. kurstaki (with Cry proteins, including Cry1 Ab) was registered by the Federal Environmental Protection Agency of the United States (US EPA) (Kumar et al., 1996; US EPA, 2016). Products based on B. thuringiensis are approved for use in agriculture in many countries of the world (APVMA 2010; UE DG SANCO 2010), mostly they are a mixture of bacterial endospores, including Cry proteins, thus the range of activity against insects is large.

Formulations based on Bacillus thuringiensis are the most successful commercial biopesticides in the biological control market accounting for $90 \%$ of all biopesticides sold all over the world (Glare and Callaghan, 2000).

The first bioinsecticide based on B. thuringiensis ssp. thuringiensis endospores was present in the form of powders for the suspensions preparation but their "adhesion" to the plant surface was very limited. According to Bechtel and Bulla (1976) parasporal crystals constitute from 20 to $30 \%$ of endospores dry 
weight. According to Schnepf et al., (1998) Cry proteins are about 20 - 30\% of bacterial cells dry weight in bioinsecticides with $B$. thuringiensis endospores, of which almost $80 \%$ are Cry1A (a, b or c), and about $20 \%$ Cry2 A or B (Abbott Laboratories, 1992).

In the 70's of the last century strain HD-1 was isolated having up to 200-fold higher insecticidal activity than previously used B. thuringiensis ssp. thuringiensis (Frankenhuyzen et al., 1993). This strain was used for the Dipel insecticide production which is produced so far. Except Dipel WG insecticide (Sumitomo Chemical, Japan), Foray 76B SC (Sumitomo Chemical Agro Europe S.A.S., France) is registered in Poland. The active substance of Foray 76B SC is $B$. thuringiensis var. kurstaki endospores and is used in the forests protection against nun moth caterpillars (Lymantria monacha L.). Bioinsecticides with $B$. thuringiensis endospores are not currently registered for maize protection in Poland. Insecticides containing $B$. thuringiensis endospores show selective and high effectiveness against crops pests. They do not affect the non-target organisms, but their regular use in the long-term may result in development of resistance in target insects (Malinowski, 1999).

\section{GM PLANTS WITH CRYIAB GENE}

Bacterial endospores used in the form of insecticides are rapidly degraded by light, they are washed off by rain and do not show systemic action, therefore cry genes have been transferred by genetic engineering methods to a number of crop species (Smith, 2005). There are 27 maize modifications with crylAb gene registered in the world, as well as 4 cotton modifications. Among the GM maize varieties there are single modification events like MON810, Bt11, Bt176, MON802 or MON809. From those, only varieties based on MON810 event can be used in European agriculture, while MON810 and Bt11 varieties can be used as food and feed in the EU. Stacking of traits by classical breeding led to the production of varieties where $c r y l A b$ gene is combined with another modification e.g. cp4-epsps herbicide tolerance gene, eg. MON810 x NK603 or pat gene, eg. T25 x MON810. GM varieties with stacked traits constantly increase in numbers. There are 10 known double modifications with crylAb gene, six lines of triple modifications, four containing four genes and one modification of five genes (until November 2016).

\section{MON810 MAIZE}

MON810 maize was first authorized GM maize in the USA (1996). In 1998, it was also authorized for cultivation and use as food and feed in the EU. In 2015, maize MON810 was cultivated on an area of about 116867 ha in 5 EU countries: the Czech Republic (997 ha), Spain (107 749 ha), Portugal (8017 ha), 
Romania (2.5 ha) and Slovakia (104 ha) (Monsanto, 2016). Genetic transformation of MON810 was performed via biolistic techniques using PV - ZMBK07 plasmid which consisted of: crylAb gene from B. thuringiensis var. kurstaki ssp. HD - 1 - encoding a Cry1 Ab protein, 35S promoter of cauliflower mosaic virus (CaMV), the maize hsp70 intron, untranslated 3' region of nopaline synthase gene (NOS) from Ti plasmid of Agrobacterium tumefaciens, sequence encoding neomycin phosphotransferase (nptII). A construct integrated into the genome for transformation event MON810 contains a $3.6 \mathrm{~kb}$ version of crylAb gene. Studies of Hernandez et al. 2003 confirmed a shortening of the sequence between positions 2235 and 2571 and the total loss of NOS terminator sequence which were confirmed by the results of Rosati et al. (2008). CrylAb protein in transgenic plants is synthesized in a truncated form, with a weight of $92 \mathrm{kDa}$. It has no $\mathrm{C}$ - or $\mathrm{N}$-terminal fragments present in bacterial protoxin, its insecticidal action requires enzymatic activation. CaMV $35 S(\mathrm{P}-35 \mathrm{~S})$ promoter used for the MON810 transformation is a constitutive promoter, however, there are reports showing that the P-35S is unevenly active in different cell types and at different developmental stages of the plant (Sunilkumar et al., 2002).

Cry $1 \mathrm{Ab}$ protein content may vary in different plant tissues and between MON810 varieties. The results of Cry1 Ab protein content analyses in leaves of 5 maize MON810 varieties indicate different content per gram of fresh weight: Agrigold A6609Bt 0.76-2.30 $\mu \mathrm{g} / \mathrm{g}$; Asgrow RX799Bt 0.77-2.39 $\mu \mathrm{g} / \mathrm{g}$; Monsanto Novelis 0.44-11.07 $\mu \mathrm{g} / \mathrm{g}$ and 0.32-11.07 $\mu \mathrm{g} / \mathrm{g}$; Pioneer P31B13Bt 0.66-2.20 $\mu \mathrm{g} /$ $\mathrm{g}$; Pioneer P33V08Bt 0.66-2.17 $\mu \mathrm{g} / \mathrm{g}$ and 0.35-0.53 $\mu \mathrm{g} / \mathrm{g}$ (Abel and Adamczyk, 2004). It is estimated that climate and soil conditions may affect the Cry $1 \mathrm{Ab}$ protein content in transgenic plants. This factor is the most common reason of differences in observed quantitative Cry1 $\mathrm{Ab}$ analyzes results. Furthermore, differences in Cry $1 \mathrm{Ab}$ content in plant tissues occur even in plants growing next to each other. This may be due to natural variability in plant metabolism and genetic or epigenetic based differences. The content of transgenic protein varies in different parts of the plant and may change during the growing season (Nguyen and Jehle, 2007). The concentration of Cry $1 \mathrm{Ab}$ measured at different stages of plant growth ranged from 0.1 to $4.89 \mathrm{mg} / \mathrm{g}$ in the stem, from 0.17 to $6.7 \mathrm{mg} / \mathrm{g}$ in pollen, from 0.2 to $5.32 \mathrm{mg} / \mathrm{g}$ in root and from 0.1 to $0.9 \mathrm{mg} / \mathrm{g}$ in seed, while the highest content was observed in leaves from 0.1 to $36.69 \mathrm{mg} / \mathrm{g}$ (US EPA, 2001; Nguyen and Jehle, 2007; Kamath et al., 2010; Szèkács and al., 2010; Habuštová et al., 2012). The highest diversity in Cry1 Ab protein content was also observed in leaves, this may be due to the fact that protein synthesis is correlated with the chlorophyll and total nitrogen content in leaves (Abel and Adamczyk, 2004; Dutton et al., 2004). According to Abel and Adamczyk (2004) the concentration of transgenic protein is related to photosynthesis rate and plant ability to produce amino acids through the photosynthesis. Related values for other tissues could indicate that in tissues which do not contain chlorophyll or possess a low level thereof, the concentration of the protein is more stable and less dependent 
on the climate and soil conditions. Due to the fact that Cry1 Ab protein content corresponds to insecticidal effectiveness of GM plants against target organisms (Adamczyk et al., 2001; Olsen et al., 2005) it is important that transgenic protein content remained stable, on sufficiently high level in tissues that are susceptible to pest attack throughout the growing season. The comparison between bacterial and Cry1 Ab protein synthesized in MON810 is shown in Table 1.

Table 1

Comparison of Cry1Ab protein in the form of a biological insecticide (Dipel WG), and in GM maize (MON810).

\begin{tabular}{lll}
\hline & \multicolumn{1}{c}{ Dipel WG } & \multicolumn{1}{c}{ MON810 } \\
\hline Protein sequence & as in B. thuringensis & as in B. thuringensis \\
Size of the protein & $131 \mathrm{kDa}$ & $92 \mathrm{kDa}$ \\
Form of the protein & protoxin & protoxin \\
$\begin{array}{l}\text { Protein size after enzymatic } \\
\text { activation }\end{array}$ & $60-70 \mathrm{kDa}$ & $60-70 \mathrm{kDa}$ \\
Plant protection & $\begin{array}{l}\text { depends on the weather conditions, time } \\
\text { of application and pest monitoring }\end{array}$ & constant through plant vegetation \\
Protein residues & during application of insecticide & through plant vegetation \\
Risk of insect resistance & $\begin{array}{l}\text { yes, requires rotation of active ingredi- } \\
\text { ent }\end{array}$ & yes, requires refugees \\
\hline
\end{tabular}

\section{CONCLUSIONS}

The insecticidal properties of Cry proteins have been used in plant protection for nearly 100 years. The most widely used agents are biological insecticides containing Cry $1 \mathrm{Ab}$ protein isolated from the soil bacterium B. thuringiensis, which is toxic to lepidopteran insects. Biological insecticides currently used are the mixture of bacterial endospores, but due to restrictions on its use, low stability and lack of systemic effect, an effective alternative in the protection of plants was demonstrated by genetically modified varieties. Since 1998 good example are MON810 maize varieties allowed to be grown in the EU, expressing the crylAb gene responsible for CrylAb protein synthesis in all tissues, throughout the entire plant growth and development. The effect of both biological insecticides and GM plants proved its effectiveness in pro-ecological pest control. However substantial differences exist in the availability of these solutions for farmers in some countries. Biological insecticides containing Cry1 Ab protein are approved for use in Poland and other EU countries also in organic farming, but require registration for relevant crop species. Although GM crops are one of the technologies approved for use in EU agriculture, in spite of proved lack of their negative effects on non-target organisms and agroecosystem, GM crops are not accepted in the organic production systems in the 
EU. Additionally the Directive of the European Parliament and of the Council (EU) 2015/412 of 11 March 2015 gives the possibility for the Member States to restrict or prohibit the cultivation of genetically modified organisms in their territory. This restriction was applied in 19 of the 28 Member States in regard to the cultivation of MON810 maize and two other maize genetic modifications (DAS $1507 \mathrm{Bt11}$ ) that are in the process of authorization for cultivation in the EU.

\section{REFERENCES}

Abel C., John A., Adamczyk J. 2004. Relative concentration of Cry1A in maize leaves and cotton bolls with diverse chlorophyll content and corresponding larval development of fall armyworm (Lepidoptera: Noctuidae) and southwestern maize borer (Lepidoptera: Crambidae) on maize whorl leaf profiles. Journal of Economic Entomology 97 (5): 1737-1744.

Abbott Laboratories. 1992. Bt Products Manual. Abbott, North Chicago, IL, USA.

Adamczyk J. J., Hardee D. D., Adams L. C., Sumerford D. V. 2001. Correlating differences in larval survival and development of bollworm (Lepidoptera: Noctuidae) and fall armyworm (Lepidoptera: Noctuidae) to differential expression of Cry1A (c) $\delta$-endotoxin in various plant parts among commercial cultivars of transgenic Bacillus thuringiensis cotton. Journal of Economic Entomology 94 (1): 284-290.

APVMA. 2010. Public Chemical Information System (PUBCRIS) [Search for Bacillus thuringiensis]. Australian Pesticides and Veterinary Management Authority (AVPMA), Symonston, Australia. http:// services.apvma.gov.au/PubcrisWebClient/.

Bechtel D. B., Bulla L. A. Jr.1976. Electron microscope study of sporulation and parasporal crystal formation in Bacillus thuringiensis. Journal of Bacteriology 1976. 127 (3): 1472-1481.

Bereś P.K., Gabarkiewicz R. 2008. Preventing spread of Ostrinia nubilalis Hbn. by cultivation of Bt transgenic maize-First field experiments in southeastern Poland. IOBC/WPRS Bulletin 33: 31-35.

Bietlot H., Carey P. R., Choma C., Kaplan H., Lessard T., Pozsgay M. 1989. Facile preparation and characterization of the toxin from Bacillus thuringiensis var. kurstaki. Biochemical Journal 260 (1): 87-91.

Bravo A., S.S., Soberón M. 2007. Mode of action of Bacillus thuringiensis Cry and Cyt toxins and their potential for insect control. Toxicon 49: 423-435.

Bravo A., Sánchez J., Kouskoura T., Crickmore N. 2002. N-Terminal Activation Is an Essential Early Step in the Mechanism of Action of the Bacillus Thuringiensis Cry1Ac Insecticidal Toxin. Journal of Biological Chemistry 277 (27): 23985-23987.

Bravo A., Likitvivatanavong S., Gill S. S., Soberón M. 2011. Bacillus thuringiensis: A story of a successful bioinsecticide. Insect Biochemistry and Molecular Biology 41 (7): 423 -31.

Crickmore N., Zeigler D. R., Schnepf E., Van Rie J., Lereclus D., Baum J., Bravo A., Dean D. H. Bacillus thuringiensis toxin nomenclature. 2010.

http://www.biols.susx.ac.uk/Home/Neil_Crickmore/Bt/index.html.

DeLucca A. J., Simonson J. G., Larson A. D. 1981. Bacillus thuringiensis distribution in soils of the United States. Canadian Journal of Microbiology 27 (9): 865-870.

Dutton A., Alessandro M. D., Romeis J., Bigler F. 2004. Assessing expression of Bt-toxin (Cry1 Ab) in transgenic maize under different environmental conditions. IOBC / WPRS Bulletin 27 (3): 49-56.

Douville M., Gagné F., Masson L., McKay J., Blaise C. 2001. Tracking the source of Bacillus thuringiensis Cry1 Ab endotoxin in the environment. Biochemical Systematics Ecology 33: 219-232.

Directive (EU) 2015/412 of the European Parliament and of the Council of 11 March 2015 amending Directive 2001/18/EC as regards the possibility for the Member States to restrict or prohibit the cultivation of genetically modified organisms (GMOs) in their territory. Official Journal of the European Union. L $68 / 1$.

Frankenhuyzen K., Gringorten J. L., Gauthier D., Milne R. E., Masson L., Peferoen M. 1993. Toxicity of activated CryI proteins from Bacillus thuringiensis to six forest Lepidoptera and Bombyx mori. Journal of Invertebrate Pathology 62: 295-301.

Frankenhuyzen K. 2013. Cross-order and cross-phylum activity of Bacillus thuringiensis pesticidal proteins. Journal of Invertebrate Pathology 114 (1): 76-85.

Gill S. S., Cowles E. A., Pietrantonio P. V. 1992. The mode of action of Bacillus thuringiensis endotoxins. Annual Review of Entomology 37:615-636. 
Glare, T. R.; O’Callaghan, M. 2000. Bacillus thuringiensis: biology, ecology and safety. Chichester: J. Wiley. $350 \mathrm{p}$.

Grochulski P., Masson L., Borisova S., Pusztai-Carey M., Schwartz J. L., Brousseau R., Cygler M. 1995. Bacillus thuringiensis CryIA(a) insecticidal toxin: crystal structure and channel formation. Journal of Molecular Biology 254 (3): 447-464.

Haider, M. Z., Ellar D. J. 1989. Functional mapping of an entomocidal $\delta$-endotoxin. Journal of Molecular Biology 208 (1): 183-94.

Hernández M., Pla M., Esteve T., Prat S., Puigdomènech P., Ferrando A. 2003. A specific real-time quantitative PCR detection system for event MON810 in maize YieldGard ${ }^{\circledR}$ based on the 3'-transgene integration sequence. Transgenic Research 12 (2): 179-89.

Hodgman T. C., Ellar D. J. 1990. Models for the structure and function of the Bacillus thuringiensis $\delta$ endotoxins determined by compilational analysis. DNA Sequence 1: 97-106.

Höfte, H., de Greve, J., Jansens S. S., Mahillon J., Ampe C., Vandekerckhove J., Vanderbruggen H., van Montagu M., Zabeau M. 1986. Structural and functional analysis of a cloned delta endotoxin of Bacillus thuringiensis Berliner 1715. European Journal of Biochemistry/FEBS 161 (2): 273-280.

Habuštová O., Doležal P., Spitzer L., Svobodová Z., Hussein H., Sehnal F. 2012. Impact of Cry1Ab toxin expression on the non-target insects dwelling on maize plants. Journal of Applied Entomology 138 (3): $164-172$.

James C. 2016. ISAAA Brief 51-2015: Executive Summary

Jurat-Fuentes J. L., Adang M. J. 2006. Cry toxin mode of action in susceptible and resistant Heliothis virescens larvae. Journal of Invertebrate Pathology 92 (3): 166-171.

Kamath S. P., Anuradha S., Vidya H .S., Mohan K. S., Dudin Y. 2010. Bacillus thuringiensis Cry1 Ab Protein in tissues of YieldGard® (MON810) corn hybrids tested at multiple field locations in India. Crop Protection 29 (9): 921-926.

Knowles B. H. 1994. Mechanism of action of Bacillus thuringiensis insecticidal $\delta$-endotoxins. In: Advances in Insect Physiology (Evans P. D., ed.). Academic Press, 24: 275-308.

Kumar P. A., Sharma R. P., Malik V. S. 1996. The insecticidal proteins of Bacillus thuringiensis. Advances in Applied Microbiology 42: 1-43.

Li J. D., Carroll J., Ellar D. J. 1991. Crystal structure of insecticidal delta-endotoxin from Bacillus thuringiensis at 2.5 a resolution. Nature 353 (6347): 815-821.

Lisowicz F., Tekiela A. 2004. Szkodniki i choroby kukurydzy oraz ich zwalczanie. s. 52-64. In: Technologia produkcji kukurydzy (Dubas A., red.). Wieś Jutra Warszawa.

Malinowski H. 1999. Stan badań nad odpornością owadów na toksyny Bacillus thuringiensis. Prace Inst. Bad. Leśn. Ser. A, 876: 53-92.

Martens J. W. M., Visser B., Vlak J. M., Bosch D. Mapping and characterization of the entomocidal domain of the Bacillus thuringiensis. Molecular and General Genetics 247 (4): 482-487.

Martin P. A. W., Travers R. S. 1989. Worldwide abundance and distribution of Bacillus thuringiensis isolates. Applied and Environmental Microbiology 55 (10): 2437-2442.

Meissle, M., Mouron, P., Musa, T., Bigler, F., Pons, X., Vasileiadis, V.P., Otto, S., Antichi,D., Kiss, J., Pálinkás, Z., Dorner, Z., van der Weide, R., Groten, J., Czembor, E., Adamczyk, J., Thibord, J.-B., Melander, B., Cordsen Nielsen, G., Poulsen, R.T.,Zimmermann, O., Verschwele, A., Oldenburg, E., 2010. Pests, pesticide use and alternative options in European maize production: current status and future prospects. Journal of Applied Entomology 134: 357-375.

Milne R., Kaplan H. 1993. Milne R., Kaplan H. 1993. Purification and characterization of a trypsin-like digestive enzyme from Spruce budworm (Choristoneura fumiferana) responsible for the activation of deltaendotoxin from Bacillus thuringiensis. Insect Biochemistry and Molecular Biology 23 (6): 663-673.

Milner R. J. 1994. History of Bacillus thuringiensis. Agriculture, Ecosystems \& Environment 49 (1): 9-13.

Monsanto. 2016. Annual monitoring report on the cultivation of MON810 in 2015. Czech Republic, Portugal, Romania, Slovakia and Spain.

Mrówczyński M., Boroń M., Wachowiak H., 2005. Ochrona kukurydzy przed szkodnikami. Program ochrony kukurydzy, Plantpress, Kraków, 7-14.

Nair M.S., Dean D.H. 2008. All domains of Cry1A toxins insert into insect brush border membranes. Journal of Biological Chemistry 283: 26324-26331.

Nguyen H. T., Jehle J. A. 2007. Quantitative analysis of the seasonal and tissue-specific expression of Cry1 Ab in transgenic maize Mon810. Journal of Plant Diseases and Protection 114 (2): 82-87.

Olsen K. M., Daly J. C., Holt H. E., Finnegan E. J. 2005. Season-long variation in expression of Cry1 Ac gene and efficacy of Bacillus thuringiensis toxin in transgenic cotton against Helicoverpa armigera (Lepidoptera: Noctuidae). Journal of Economic Entomology 98 (3): 1007-1017.

Pigott C. R., Ellar D. J. 2007. Role of Receptors in Bacillus thuringiensis crystal toxin activity. Microbiology and Molecular Biology Reviews: 71 (2): 255-281. 
Rosati A., Bogani P., Santarlasci L., Buiatti M., 2008. Characterisation of $3^{\text {ee }}$ transgene insertion site and derived mRNAs in MON810 YieldGard maize. Plant Molecular Biology 67: 271-281

Saladini M.A., Blandino M., Reyneri A., Alma A. 2008. Impact of insecticide treatments on Ostrinia nubilalis (Hübner) (Lepidoptera: Crambidae) and their influence on the mycotoxin contamination of maize kernels. Pest Management Science 64 (11): 1170-1178.

Schnepf E., Crickmore N., Van Rie J., Lereclus D., Baum J., Feitelson J., Zeigler D. R., Dean D. H. 1998. Bacillus thuringiensis and its pesticidal crystal proteins. Microbiology and Molecular Biology Reviews: 62 (3): 775-806.

Schwartz J.L., Lu Y.J., Sohnlein P., Brousseau R., Laprade R., Masson L., Adang M.J. 1997. Ion channels formed in planar lipid bilayers by Bacillus thuringiensis toxins in the presence of Manduca sexta midgut receptors. FEBS Letters 412: 270-276.

Smith C. M. 2005. Plant Resistance to Arthropods. Molecular and Conventional Aproaches: 303-343.

Soberón M., Pérez R. V., Núñez-Valdez M. E., Lorence A., Gómez I., Sánchez J., Bravo A. 2000. Evidence for intermolecular interaction as a necessary step for pore formation activity and toxicity of Bacillus thuringiensis Cry1Ab toxin. FEMS Microbiology Letters 191: 221-225.

Soberón M., Pardo L., Muñóz-Garay C., Sánchez J., Gómez I., Porta H., Bravo A. 2010. Pore formation by Cry toxins. p. 127-142. In: Proteins membrane binding and pore formation (Anderluh G. and Lakey J., eds.),. Advances in Experimental Medicine and Biology 677, Springer New York.

Sunilkumar G., Mohr L. A., Lopata-Finch E., Emani C., Rathore K. S. 2002. Developmental and tissuespecific expression of CaMV 35S promoter in cotton as revealed by GFP. Plant Molecular Biology 50 (3): $463-474$.

Székács A., Lauber E., Juracsek J., Darvas B. 2010 a. Cry1Ab toxin production of MON 810 transgenic maize. Environmental Toxicology and Chemistry 29 (1): 182-190.

UE DG SANCO. 2010. EU Pesticides Database [Search for Bacillus thuringiensis ]. European Union Directorate General, Health and Consumers (EU DG SANCO) Belgium http://ec.europa.eu/sanco pesticides/ public/index.cfm?event=activesubstance.selection

US EPA. 2016. Biopesticide registration action document. Bacillus thuringiensis (Bt) plant incorporated protectants. United States Environmental Protection Agency, Washington. https://www.epa.gov/ ingredients-used-pesticide-products/what-are-biopesticides

Whiteley H. R., Schnepf H. E. 1986. The molecular biology of parasporal crystal body formation in Bacillus thuringiensis. Annual Review of Microbiology 40: 549-576.

Zhang X., Candas M., Griko N. B., Taussig R., Bulla L. A. 2006. A mechanism of cell death involving an adenylyl cyclase/PKA signaling pathway is induced by the Cry1 Ab toxin of Bacillus thuringiensis. Proceedings of the National Academy of Sciences USA 103 (26): 9897-9902 